\title{
Conjunctival metastasis of a renal cell carcinoma in a 59-year-old man - clinicopathological case report
}

\section{Przerzut raka jasnokomórkowego nerki do spojówki u 59-letniego mężczyzny - opis przypadku}

\author{
Ewa Dernoga ${ }^{1}$, Iwona Rospond-Kubiak ${ }^{1}$, Jarosław Kocięcki ${ }^{1}$, Andrzej Marszałek² \\ ${ }^{1}$ Department of Ophthalmology, Poznan University of Medical Sciences, Poznan, Poland \\ Head of the Department: Prof. Jarosław Kocięcki MD, PhD \\ ${ }^{2}$ Department of Oncologic Pathology, Chair of Oncology, Poznan University of Medical Sciences, Poznan, Poland \\ Head of the Department: Prof. Andrzej Marszałek MD, PhD
}

Key words: metastasis, renal cell carcinoma, conjunctiva.

Słowa kluczowe: przerzut, rak jasnokomórkowy nerki, spojówka.

\begin{abstract}
The aim of the study was to present a rare case of conjunctival metastasis of a renal cell carcinoma. A 59-year-old man presented in 2012 with rapidly growing, painless, and occasionally bleeding right eye conjunctival tumour. The patient had a history of advanced renal cell carcinoma diagnosed 3 weeks previously. The conjunctival tumour was resected, and histopathological report confirmed the working diagnosis of a metastatic tumour. The patient received palliative radiation to the central nervous system but died from disseminated disease 8 weeks later. Conjunctival metastasis of a renal cell carcinoma is exceedingly rare. It appears in a stage of disseminated disease.
\end{abstract}

\section{Streszczenie}

Celem pracy jest przedstawienie rzadkiego przypadku przerzutu raka jasnokomórkowego nerki do spojówki. Autorzy prezentują przypadek 59-letniego mężczyzny z gwałtownie wzrastającym, bezbolesnym, okresowo krwawiącym guzem spojówki oka prawego. U pacjenta w wywiadzie 3 tygodnie wcześniej rozpoznano zaawansowanego raka nerki jasnokomórkowego (RCC). Guz spojówki został usunięty chirurgicznie, a badanie histopatologiczne potwierdziło postawioną wstępnie diagnozę guza przerzutowego. Pacjent otrzymał paliatywną radioterapię na okolicę ośrodkowego układu nerwowego, zmarł 8 tygodni później w następstwie rozsiewu choroby podstawowej. Przerzut raka nerki jasnokomórkowego do spojówki jest niezwykle rzadki. Jest charakterystyczny dla zaawansowanego stadium rozsianej choroby nowotworowej.

\section{Introduction}

Renal cell carcinoma (RCC) is a malignant kidney cancer that originates from the proximal or distal renal tubular epithelium. Renal cell carcinoma accounts for $2-3 \%$ of all adult malignant tumours, and men are generally affected two times more frequent than women [1]. It normally appears in the sixth decade of a patient's life. Five-year survival for disseminated RCC is estimated at less than $10 \%$ [2]. The most common metastatic locations of RCC are lungs (76\%), regional lymph nodes (66\%), bones (42\%), liver (41\%), and brain $(8 \%)[3,4]$. In Poland, about 2500 people die every year from disseminated RCC [5].

Ocular and orbital metastases from RCC are uncommon. In a detailed analysis of 227 metastatic tumours to the eye and orbit, Ferry and Font [6] recognised only seven lesions (3.5\%) originating from the renal carcinoma.
In this report we would like to present the case of a 59-year-old man with conjunctival metastasis of RCC and a rapid growth rate.

\section{Case report}

A 59-year-old man presented to the Ocular Oncology Service in July 2012 with a right eye conjunctival tumour which he had recognised 1 week previously. The tumour was painless, occasionally bleeding, and growing fast. The patient had a history of right nephrectomy for RCC 2 weeks prior to developing any ophthalmolo-gical symptoms. Histopathological report identified RCC of mixed structure: partially sarcomatoid and partly clear cell (G4pT3b). At presentation, metastases to the central nervous system and left tonsil were also present. 

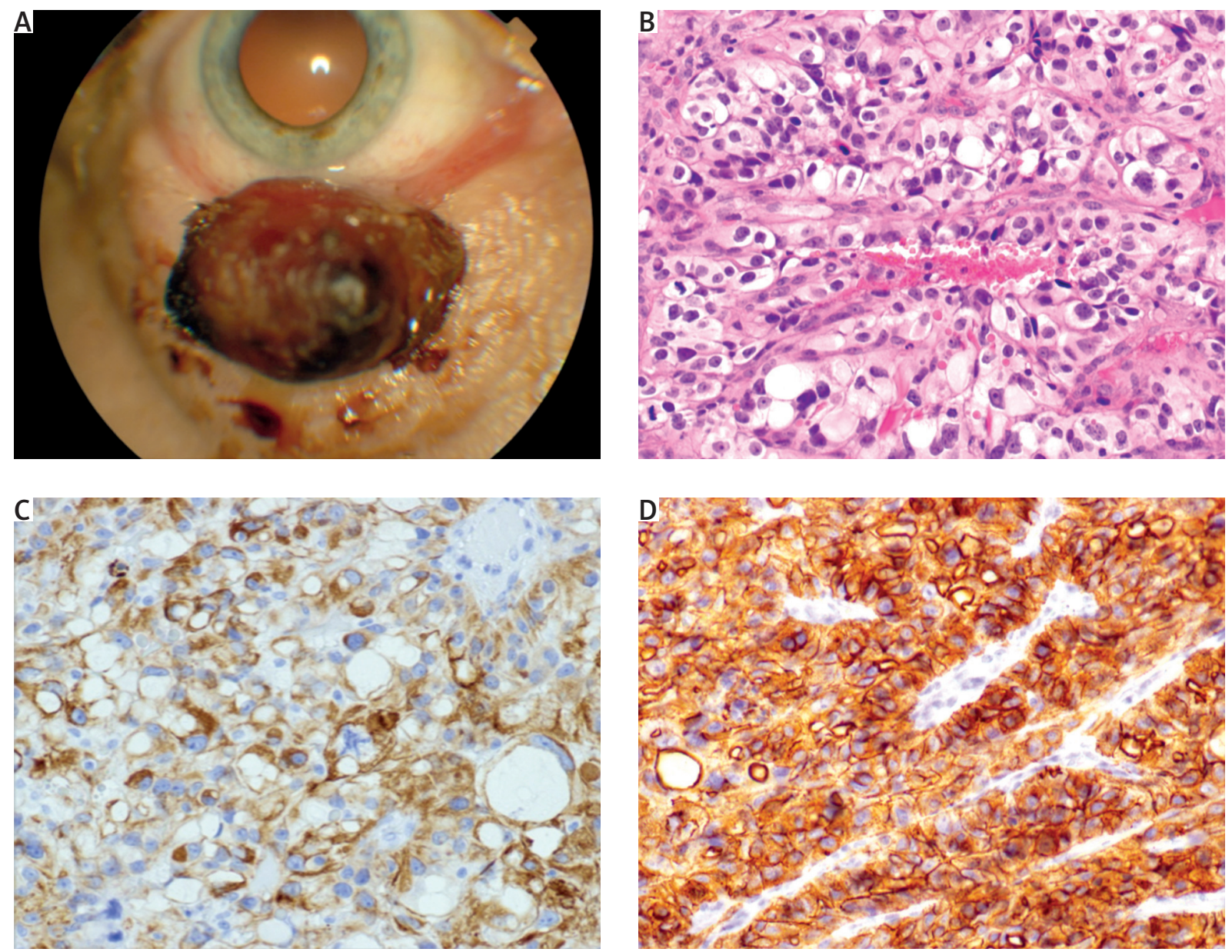

Figure 1. A - Clinical appearance of conjunctival tumour at presentation, B - H + E staining. C, D - positive stains for CD20 (+) and CAM.5, respectively

On examination, the best-corrected visual acuity (BCVA) was $5 / 5$ in the Snellen scale in the affected eye and $5 / 5$ in the left eye, which was healthy. There was a conjunctival mass located in the right lower fornix protruding forward and involving the lower lid (Figure $1 \mathrm{~A})$. The tumour was reddish in colour with blood clots on its surface measuring $16 \mathrm{~mm} \times 6 \mathrm{~mm} \times 10 \mathrm{~mm}$. Fundoscopy of the right eye revealed no pathology. The working diagnosis of conjunctival metastasis was made and the tumour was excised urgently.

The histopathological and immunohistochemical evaluation following the surgery showed metastasis of the RCC with the expression of CD10+ and CAM5.2+ (Figures 1 B-D). The staining for CK7was negative. The surgical margins were clear. Due to disseminated disease the patient was managed by the oncologist, who decided about palliative radiotherapy in July 2012. Despite the received treatment, the patient died in September 2012. During the follow-up period we did not notice any tumour recurrence.

\section{Discussion}

This is a clinicopathological case report of an exceedingly rare conjunctival metastasis of a renal cell carcinoma. The metastatic tumour was suspected at initial presentation because of the recent history of disseminated renal cancer and rapid growth rate. Histopathological and immunohistochemical tests following the surgery confirmed the initial diagnosis.

The differential diagnosis for this case would be: conjunctival angioma, squamous cell carcinoma, melanoma, oncocytoma, mucoepidermoid cancer, and Kaposi's sarcoma. The other possible primary locations of the metastasising cancer could be: breast, lung, skin melanoma, larynx, stomach, urinary bladder, colon, and testicle [7]. All of these could be excluded on the basis of the histopathological report.

There are about 71 cases of eye and orbit metastases from kidney cancer reported in the literature. The in- 
volved structures were: orbit (36.8\%), choroid (29.4\%), iris (10.3\%), ciliary body (5.9\%), lacrimal gland (2.9\%), conjunctiva (1.5\%), eyelid (1.5\%), and extraocular muscle (1.5\%) [8]. The conjunctival metastases normally appear in the advanced stage of the disease.

Three cases of conjunctival metastases of RCC have been published so far. In two of them $[9,10]$ the intraocular structures were also involved and the patients presented with visual loss. The third one with conjunctival involvement had not experienced such a fast growth rate [11] as our patient. All described tumours occasionally bled, and this seems to be typical for RCC conjunctival metastasis [9-11].

In conclusion, conjunctival metastases from renal cell carcinoma are rare. The metastatic renal tumour can be suspected with a reddish colour of the mass and rapid growth rate. In any case, urgent excision of the tumour is required.

\section{Conflict of interest}

The authors declare no conflict of interest.

\section{References}

1. Szczylik C, Wcisło G (eds). Rak nerki. Współczesna diagnostyka i terapia. Termedia, Poznan 2010; 17.

2. Waalkes S, Schreder AJ, Kuczyk MA. Current treatment options for disseminated renal cell carcinoma. Eur Urol Suppl 2012; 11: 73-8.

3. Pompeu AC, Arap S, Silva MN, Monteiro DS. Ocular metastasis as first presentation of renal cell carcinoma: report of 2 cases. Clinics 2005; 60: 75-8.

4. Bianchi M, Sun M, Jeldres C, Shariat SF, Trinh QD, Briganti A, Tian Z, Schmitges J, Graefen M, Perrotte P, Menon M, Montorsi F, Karakiewicz PI. Distribution of metastatic sites in renal cell carcinoma: a population-based analysis. Ann Oncol 2012; 23: 973-80.

5. Kordek R, Jassem J, Jeziorski A, Kornafel J, Krzakowski M, Pawlęga J. Onkologia. Podręcznik dla studentów i lekarzy. Via Medica, Gdańsk 2013; 246.

6. Ferry AP, Font RL. Carcinoma metastatic to the eye and orbit. I. A clinicopathologic study of 227 cases. Arch Ophthalmol 1974; 92: 276-86.

7. Kiratli H, Shields CL, Shields JA, DePotter P. Metastatic tumours to the conjunctiva: report of 10 cases. $\mathrm{Br} \mathrm{J} \mathrm{Oph-}$ talmol 1996; 80: 5-8.

8. Shome D, Honavar SG, Gupta P, Vemuganti GK, Reddy PV. Metastasis to the eye and orbit from renal cell carcinoma: a report of three cases and review of literature. Surv Ophthalmol 2007; 52: 213-23.

9. Ware GT, Haik BG, Morris WR. Renal cell carcinoma with involvement of iris and conjuctiva. Am J Ophtalmol 1999; 127: 460-1.

10. Rodney AJ, Gombos DS, Fuller GN, Pagliaro LC, Tannir NM. Choroidal and conjunctival metastases from renal cell carcinoma Am J Clin Oncol 2009; 32: 448-9.

11. Lapp T, Mittelviefhaus H, Werner M, Auw-Hadrich C. Severe bleeding eyelid after trivial trauma: conjuctival metastasis of a renal cel carcinoma. Graefes Arch Clin Exp Ophtalmol 2012; 250: 1705-6.

\author{
Address for correspondence: \\ Ewa Dernoga \\ Department of Ophthalmology \\ Poznan University of Medical Sciences \\ ul. Długa 1/2, 61-848, Poznań, Poland \\ Phone: +48 606535099 \\ E-mail: edernoga@tlen.pl
}

